\title{
Studies on Histochemical Observations of Malignant Cells by Coriphosphine 0 Staining
}

\author{
Takashi Korsuka and Yasuhiko MrYake
}

\author{
Hiraki clinic, Department of Internal Medicine, Okayama University Medical School
}

The acridine orange (AO) fluorescence method for the diagnosis of cancer, developed by L. von Bertalanffy ${ }^{1}$, utilizes increased amounts of cytoplasmic ribonucleic acid in malignant cells to demonstrate them in brilliant reddish orange colors. Many authors have studied the method for the cytodiagnosis of cancer with materials from the female genital truct ${ }^{2-4}$, gastric washings ${ }^{(5)}$ ), and sputum ${ }^{8,9}$. Coriphosphine $O(\mathrm{CO})$ staining has been used conventionally for the use of RNA marker on tissue culture cells, frozen sections, and other specimens. However no practical works have been reported for the cytodiagnosis of cancer with $\mathrm{CO}$ staining. In this paper we studied the representation of PNA in malignant cells to test the diagnostic reliability of $\mathrm{CO}$ staining, comparing with those of stained independently by $\mathrm{AO}$ fluorescence method ${ }^{11}$ on different smears from the same specimens.

\section{Materials and Methods}

The material for this study was divided into 3 categories (table 1); a) Routine exfoliative material from sputum, pleural and ascitic fluids, and gartric washings ( $\alpha$-chymotrypsin solution at pH. 5.6 was used). b) Frozen sections from gastric biopsies (Rubin's suction biopsy ${ }^{(0)}$ ). c) Bone marrow aspirates from patients of hematological disorders. Each type of sample was processed in various manner ; 1) Moist or dried preparations were fixed in ether-alcohol, or Carnoy's solution. 2) They were hydrated through $80 \%, 70 \%, 50 \%$ alcohol to distilled water, or simply they were passed through 196 acetic acid three times. 3) They were placed for 10 minutes into McIllvaine's buffer at $\mathrm{pH}$. 4.8-5.8. 4) They were stained with CO solutions, diluted to $1: 10,000$ with each buffer solution. Staining time was varied from 2 to 20 minutes at room temperature, or in cold chamber at $5^{\circ} \mathrm{C}$. 5) They were washed in each buffer solution for 3,5 , or 10 times repeatedly. 6) Then, they were dried and covered with $10 \%$ buffered glycerol. 7) Fluorescence microscopic observations were carried out with BV exciting system using CHIYODA H 250 high pressure mercury vapour lamp. 8) Preparations from the same material were independently stained with the procedure of May-Giemsa and AO fluorescence method".

\section{Result}

A. Optimal staining procedure. In the most defined preparations brilliant fluorescence was observed with green, yellow, brown, and reddish orange colors. 
Table 1.

\begin{tabular}{|c|c|c|c|c|}
\hline & malignant & non-malignant & $\begin{array}{l}\text { hematological } \\
\text { disorders }\end{array}$ & $\begin{array}{l}\text { total number } \\
\text { of cases }\end{array}$ \\
\hline gastric washings & 22 & 29 & - & 51 \\
\hline gastric biopsies & 10 & 19 & 12 & 41 \\
\hline ascitic fluids & 12 & 2 & - & 14 \\
\hline pleural fluids & 8 & 1 & - & 9 \\
\hline sputum & 2 & 1 & - & 3 \\
\hline $\begin{array}{l}\text { bone marrow } \\
\text { aspirates }\end{array}$ & - & - & 5 & 5 \\
\hline $\begin{array}{l}\text { total number } \\
\text { of cases }\end{array}$ & 54 & 52 & 17 & 123 \\
\hline
\end{tabular}

In the smear frum exfoliative material, the optimal procedure was as follows; Moist smears were fixed in ether-alcohol for 20 minutes, passed through $1 \%$ acetic acid three times, and placed into buffer solution for 10 minutes at $\mathrm{pH}$. 5.2-5.4, and stained with buffered $\mathrm{CO}$ solution for 7 minutes at room temperature, and then they were washed with buffer at the same $\mathrm{pH}$. for 5 times. In bone marrow smears, the optimal staining was observed at the $\mathrm{pH}$. of 5.4 to 5.6. Frozen sections were dried and fixed with Carnoy's solution for 5 minutes, hydrated through $80 \% 6,70 \%, 50 \%$ alcohol to distilled water, buffered at $\mathrm{pH}$. $5.0-5.2$, and stained by the same way.

B. Fluorescence microscopic findings. 1) Gastric exfoliated cells. In normal epithelial cells or glandular cells, clear green fluorescence was observed in nuclei, and dull greenish brown in cytoplasm. In non-malignant atypical cells, nuclei revealed yellowish brown fluorescence, and cytoplasm reddish brown. In malignant cells distinguished reddish orange fluorescence was observed in cytoplasm and nucleoli, but yellowish orange in nuclei. Because of this remarkable fluorescence, malignant cells were detected quickly even at low magnification. 2) Frozen sections from gastric biopsies. In the preparations from normal gastric membrane, nuclei of epithelial cells, connctive tissue cells, and infiltrated cells were revealed dull green fluorescence and cytoplasm of them faint green. In fundic glands, bright yellowish green fluorescence was observed in nuclei, and dirty brown or greenish brown in cytoplasm. In the chronic atrophic gastritis remarkably increased fluorescence was observed with bright reddish brown color in epithelial layer and fundic glands. In the tissue of adenocarcinoma ventriculi, brilliant reddish orange fluorescence was observed in the cytoplasm of cancer cells. 3) In sputum and pleural or ascitic fluids, and bone marrow aspirates, dirty brown or reddish brown fluorescence was observed in cytoplasm of dust cells, phagocytes and leukocytes against bright green fluorescence of nuclei. However no brilliant fluorescence was observed as those of cancer cells.

C. Correlation with $\mathrm{CO}$ staining and nucleic acid. Smears from malignant ascitic fluid were treated with $\mathrm{RN}$ ase and $\mathrm{DN}$ ase before the routine procedure of $\mathrm{CO}$ staining was performed. In the preparation treated with $0.1 \% \mathrm{RN}$ ase 
Table 2.

\begin{tabular}{|c|c|c|c|c|c|}
\hline \multirow{2}{*}{$\begin{array}{l}\text { total number of cases } \\
\text { correctly diagnosed }\end{array}$} & \multirow{2}{*}{$\begin{array}{l}\text { methods of } \\
\text { cytodiagnosis }\end{array}$} & \multicolumn{3}{|c|}{$\begin{array}{l}\text { classification of } \\
\text { malignancy }\end{array}$} & \multirow{2}{*}{$\begin{array}{c}\text { sensitivity of } \\
\text { cytodiagnosis } \\
(\%)\end{array}$} \\
\hline & & I-II & III & IV-V & \\
\hline \multirow{3}{*}{$\begin{array}{l}\text { gastric cancer } \\
22 \text { cases }\end{array}$} & MG & 3 & 2 & 17 & 77.3 \\
\hline & $\mathrm{AO}$ & 2 & 1 & 19 & 86.4 \\
\hline & $\mathrm{CO}$ & 2 & 0 & 20 & 90.9 \\
\hline \multirow{3}{*}{$\begin{array}{l}\text { chronic gastritis } \\
24 \text { cases }\end{array}$} & MG & 18 & 5 & 1 & 79.2 \\
\hline & $\mathrm{AO}$ & 23 & 0 & 1 & 95.8 \\
\hline & $\mathrm{CO}$ & 23 & 0 & 1 & 95.8 \\
\hline \multirow{3}{*}{ gastric ulcer 5 cases } & MG & 4 & 1 & 0 & 80.0 \\
\hline & AO & 5 & 0 & 0 & 100.0 \\
\hline & $\mathrm{CO}$ & 5 & 0 & 0 & 100.0 \\
\hline
\end{tabular}

MG : May-Giemsa stain, AO : acridine orange fluorescence method, $\mathrm{CO}$ : coriphosphine $\mathrm{O}$ fluorescence method.

solution for 30 minutes at $37^{\circ} \mathrm{C}$, nuclei of cancer cells revealed faint green fluorescence, and in nucleoli and cytoplasm of them no fluorescence was observed. In the preparation treated with $\mathrm{DN}$ ase solution, green fluorescence was completely diminished from nuclei of cancer cells. Furtheremore, PN ase and DN ase solution were repeatedly overflown, and then any fluorescence was seen in the preparation.

D. An evaluation of $\mathrm{CO}$ fluorescence method to cancer screening of stomach. Fifty two cases of gastric lesions were screened by gastric washings. Twenty three cases of them were malignant, others no malignant. Cytodiagnosis by $\mathrm{CO}$ fluorescence method was compared with $\mathrm{AO}$ fluorescence method and May-Giemsa stain (table 2). Consequently, high sensitivity of cytodiagnosis was obtained by $\mathrm{CO}$ fluorescence method, much or less higher than those by AO fluorescence method and remarkably superior to May-Giemsa stain.

\section{Discussion}

Fluorescence microscopy has been applied to cytology using berberin sulfate, acid fuchsin and the acridine group of stains ${ }^{2}$. $\mathrm{CO}$ and $\mathrm{AO}$ are both included to the acridine group. Its application for cytodiagnosis of cancer cells is based on the affinity of the basic fluorochrome dyes for the nucleic acid. Although most malignant cells have more nucleic acids than their normal prototypes ${ }^{11}$, some cancer cells have no significant increase in $\mathrm{DNA}^{12}$, and decreased RNA has been found in some malignant cells ${ }^{13}$. Thus it is not surprising that some exfoliated malignant cells revealed no significant fluorescence, but most of malignant cells reveal brilliant reddish orange fluorescence because of increased amounts of RNA. Most of false negative diagnosis in this study were due to technical failure, caused by unsufficient washing or rapid degeneration owing to reversed bile. As a result, it was proved that the sensitivity of cytodiagnosis of cancer by $\mathrm{CO}$ fluorescence method was equal to that by $\mathrm{AO}$ 
fluorescence method, and that both fluorescence method have the same advantages and the same disadvantages.

\title{
Conclusions
}

Coriphosphine $\mathrm{O}$ fluorescence method for cytodiagnosis of cancer cells was studied. The sensitivity of cancer screening by Coriphosphine $O$ procedure was much or less higher than that by acridine orange procedure, and remarkably superior to that by conventional staining.

\section{References}

1) von Bertalanffy, L.: Identification of cytoplasmic basophilia (ribonucleic acid) by fluorescence microscopy, J. Histochem. Cytochem., 4:481-493, 1956. 2) Friedman, H. P.: The use of ultraviolet light and fluorescent dyes in the detection of uterine cancer by vaginal smear, Am. J. Obst. Gynecol., $59: 852-859,1950 . \quad 3)$ Bertalanffy, F. D.: Diagnostic reliability of the acridine orange fluorescence microscope method for cytodiagnosis of cancer, Cancer Res., $21: 422-426,1961.4$ 4) Bertalanffy, F. D. : Evaluation of the acridine orange fluorescence microscope method for cytodiagnosis of cancer, Ann. New York Acad. Sc., $93: 715-750,1962 . \quad 5)$ Scheiner, S. L. : Fluorescence cytologic screening, Arch. Surg., $85: 948-954,1962 . \quad 6)$ Hitchcock, C. R. : Early diagnosis of gastric cancer, Surg. Gynecol. Obst., $113: 665-672,1961 . \quad 7)$ Ventzke, L. E.: Fluorescence microscopy with acridine orange in gastrointestinal cytology, Gastroenterol., $45: 712-717,1963 . \quad 8)$ Umiker, W. et al: Fluorescence microscopy in exfoliative cytology, Brit. J. Cancer, $13: 398-402,1961$. 9) Wwellmann, K. F. : An evaluation of acridine orange fluorescence microscopy in cytology, Acta Cytol., $7: 111-117,1963 . \quad 10)$ Brandborg, L. L., Rubin, G. E. et al : A multipurpose instrument for suction biopsy of the esophagus, stomach, small bowel and colon, Gastroentel., $37: 1-16,1957$. 11) Mellors, R. C. et al : Microfluorometric scanning method for detection of cancer cells in smear of exfoliated cells, Cancer, $5: 458-468,1952$. 12) Cunningham, L. et al : J. gen. Physoil., $34: 59,1950 . \quad 13)$ Casperson, T. et al : Studies on protein metabolism in the cells of epithelial tumors, Acta Radiol., $46: 5-100,1942$.

\section{Histochemical Studies of Proteinase of Tumor Cells}

\author{
Kiyoshi Kumazawa \\ (Department of Pathology. The Tuberculosis Research Institute \\ of Kyoto University: Director. Prof. H. Takamatsu.)
}

Since the publication of histochemical demonstiation method of proteinase by Takamatsu and $\mathrm{Wada}^{1)}{ }^{-4)}$ in which protein was stained previously with dye such as methylen blue and used as substrate of the enzyme, many studies on the histochemical reaction of proteinase in tumor tissues of human and also other animal races were reported by many researchers in this country. In general, tumor cells showed the staining reaction intensively. 